\title{
The Role of Oxide Thin Layer in Inverted Structure Polymer Solar Cells
}

\author{
Orawan Wiranwetchayan ${ }^{1,2}$, Zhiqiang Liang ${ }^{1}$, Qifeng Zhang ${ }^{1}$, Guozhong Cao ${ }^{1 *}$, Pisith Singjai ${ }^{2}$ \\ ${ }^{1}$ Department of Materials Science and Engineering, University of Washington, Seattle, USA; ${ }^{2}$ Department of Physics and Material \\ Science, Faculty of Science, Chiang Mai University, Chiang Mai, Thailand. \\ E-mail: "gzcao@u.washington.edu
}

Received September $19^{\text {th }}, 2011$; revised October $24^{\text {th }}, 2011$; accepted November $6^{\text {th }}, 2011$.

\begin{abstract}
The role of wide band gap oxide thin layer in inverted structure polymer solar cells was investigated by employing oxide films of $\mathrm{TiO}_{2}$ and $\mathrm{Nb}_{2} \mathrm{O}_{5}$ approximately $10 \mathrm{~nm}$ in thickness deposited onto FTO substrates. The experimental results demonstrated that the thin oxide layer serving to separate the electron collecting electrode and the photoactive film of a blend of poly(3-hexylthiophene) (P3HT) and phenyl-C61-butyric acid methyl ester (PCBM) was necessary to promote the formation of continuous uniform PCBM film to block holes in P3HT from being recombined with electrons in collecting electrode. A use of $\mathrm{TiO}_{2}$ buffer layer leads to power conversion efficiency as high as $2.8 \%$. As for $\mathrm{Nb}_{2} \mathrm{O}_{5}$, in spite the fact that its conduction band is higher than the LUMO level of PCBM polymer acting as electron transport material, a power conversion of $2.7 \%$, which was only slightly different from the $2.8 \%$ achieved for the cell employing $\mathrm{TiO}_{2}$. These experimental results suggest a tunneling mechanism for the electrons to transport from the PCBM to collecting electrode over the oxide film, instead of a diffusion through the oxide film arising from either energy or concentration difference of the photogenerated electrons.
\end{abstract}

Keywords: Polymer Solar Cell, Oxide Thin Film, $\mathrm{TiO}_{2}$ Thin Film, $\mathrm{Nb}_{2} \mathrm{O}_{5}$ Thin Film

\section{Introduction}

Photovoltaic cells based on conjugated polymer and fullerene bulk heterojuction composites have attracted much attention for renewable energy due to their promising properties such as low production cost, their lightness, light weight, mechanical flexibility and the possibility of fabricating them on large area [1-5]. Recent the power conversion efficiency (PCE) of the bulk heterojunction polymer solar cells has reached as high as $7.4 \%$ in conventional device structures [6]. Conventional organic photovoltaics, OPVs generally consist of an active layers sandwiched by a high work function and transparent metal oxide as the anode such as PEDOT:PSS and a low function metal as the cathode such as $\mathrm{Al}$ [7]. In spite of high PCE, the conventional OPVs can suffer from degradation of the cathode due to their sensitivity to oxygen and moisture in air. Therefore, the devices in this structure exhibit short lifetime [8-10]. In order to overcome these problems, the inverted device structures is an alterative solution to improve the durability, because it uses a more air-stable high work function electrode such (Ag, $\mathrm{Au}$ ) as back contact to collect holes while using an inorganic semiconductor for buffer layer to collect electrons.
The usage of inorganic semiconductor embedded into the conjugated polymer have several attributes as electron acceptors, including relatively high electron mobility, high electron affinities, hole-blocking ability and good physical and chemical stability [11-16].

In this work we report the fabrication of inverted polymer solar cells and investigate the role of thin dense metal oxide films in the inverted polymer solar cells using dense film of $\mathrm{TiO}_{2}$ and $\mathrm{Nb}_{2} \mathrm{O}_{5}$. These two oxides were purposely selected in view of the bottom of conduction band of $\mathrm{TiO}_{2}$ lower than the LUMO level of PCBM and that of $\mathrm{Nb}_{2} \mathrm{O}_{5}$ higher than the LUMO level of PCBM. It was found that such a very thin metal oxide films between the electron collecting electrode and active layers was necessary to promote the formation of continuous uniform PCBM film and thus block the holes in $\mathrm{P} 3 \mathrm{HT}$ from being recombined with the electrons in collecting electrode.

\section{Experiment Details}

\subsection{Preparation of $\mathrm{TiO}_{2}$ Sol and $\mathrm{Nb}_{2} \mathrm{O}_{5}$ Sol}

$\mathrm{TiO}_{2}$ sol was prepared by hydrolyzing titanium alkoxide in an acidic aqueous. Typically, $1 \mathrm{~mL}$ of titanium iso- 
propoxide was added to $20 \mathrm{~mL}$ of distilled water containing $0.5 \mathrm{~mL}$ of hydrochloric acid. A white precipitate appeared in the beginning. After stirring for about $30 \mathrm{~min}$, the precipitate completely dissolved, resulting in the formation of a $\mathrm{TiO}_{2}$ sol in light yellow color. The fabriccation of $\mathrm{Nb}_{2} \mathrm{O}_{5}$ sol was adopted a similar process and recipe, except the replacement of titanium isopropoxide with niobium ethoxide.

\subsection{Fabrication of Solar Cell Devices}

The FTO glass substrate was cleaned with DI water, acetone and isopropanol. The sol of $\mathrm{TiO}_{2}$ or $\mathrm{Nb}_{2} \mathrm{O}_{5}$ was employed to form a thin film on the FTO glass substrate through a spin-coating method. The substrates with $\mathrm{TiO}_{2}$ or $\mathrm{Nb}_{2} \mathrm{O}_{5}$ thin film then suffered a thermal treatment at $450^{\circ} \mathrm{C}$ for $1 \mathrm{~h}$ to convert the $\mathrm{TiO}_{2}$ or $\mathrm{Nb}_{2} \mathrm{O}_{5}$ to crystalline phase. A chlorobenzene solution of P3HT: PCBM (1:0.8 by weight) containing $20 \mathrm{mg} / \mathrm{ml} \mathrm{P} 3 \mathrm{HT}$ and $16 \mathrm{mg} / \mathrm{ml}$ PCBM was prepared by stirring in glovebox at $60^{\circ} \mathrm{C}$ for overnight. The solutions were allowed to cool down to room temperature and then filtered with a $0.2 \mu \mathrm{m}$ polytetrafluoroethylene (PTFE) filter. For the device fabrication, the as-prepared $\mathrm{P} 3 \mathrm{HT} / \mathrm{PCBM}$ blend solution was spin-coated onto the FTO glass substrate coated with $\mathrm{TiO}_{2}$ or $\mathrm{Nb}_{2} \mathrm{O}_{5}$ thin film (note: at $1000 \mathrm{rmp}$ for $30 \mathrm{~s}$ ) pretreated with oxygen plasma for $10 \mathrm{~min}$. The samples were then baked at $225^{\circ} \mathrm{C}$ for $1 \mathrm{~min}$ to allow self-organization of P3HT, as well as to remove residual solvent and to some extent improve the contact between the polymer and oxide film. On the P3HT: PCBM blend layer, a diluted poly (3,4-ethylene-dioxylene thiophene)-poly (styrene sulfonic acid) (PEDOT:PSS, Clevios P VP AL 4083) solution was spin-coated to form hole-transport layer. The films were consequently baked at $120^{\circ} \mathrm{C}$ for $10 \mathrm{~min}$. Finally, a $100 \mathrm{~nm}$ thick silver film was deposited on the PEDOT:PSS to work as top electrode.

Figure 1 shows a schematic configuration of the asfabricated inverted polymer solar cell. The semiconducting metal oxide $\mathrm{TiO}_{2}$ and $\mathrm{Nb}_{2} \mathrm{O}_{5}$ thin films are approximately $10 \mathrm{~nm}$ in thickness characterized by observing the cross-section SEM image of the films. The thicknesses of the polymer layer are about $300 \mathrm{~nm}$ and $30 \mathrm{~nm}$ for P3HT:PCBM and PEDOT:PSS, respectively.

\section{Results and Discussion}

Prior to investigation of the as-prepared inverted structure polymer solar cells, a device with structure of FTO/P3HT:PCBM/PEDOT/Ag, i.e., not including an oxide thin film to separate the FTO glass substrate and polymer layers, was studied as a reference. The result is shown in Figure 2. One can see that there is no photovoltaic response at all. This is in agreement with what is pointed out in literature that an inverted structure poly- mer solar cell includes a buffer layer to prevent direct contact between the FTO and polymer layers.

Shown in Figure 3 are the current density $(J)$-voltage $(V)$ curves of the inverted structure polymer solar cells, in which a layer of $\mathrm{TiO}_{2}$ or $\mathrm{Nb}_{2} \mathrm{O}_{5}$ thin film was deposited on FTO glass substrate to separate the blend of P3HT and PCBM polymers and the collecting electrode. It can be seen that for the substrates using $\mathrm{TiO}_{2}$ and $\mathrm{Nb}_{2} \mathrm{O}_{5}$ dense films the values of short-circuit current density $\left(J_{s c}\right)$ and open-circuit voltage $\left(V_{o c}\right)$ show very small difference. Power conversion efficiencies $(\eta)$ for the cells with $\mathrm{TiO}_{2}$ and $\mathrm{Nb}_{2} \mathrm{O}_{5}$ are $2.8 \%$ and $2.7 \%$, respectively. Taking into account the above result shown in Figure 2, it strongly suggests that a thin metal oxide film as buffer layer between the electron collecting electrode and the blend of P3HT and PCBM polymers is necessary to form inverted structure hybrid solar cells.

A dependence of the solar cell efficiency on the thickness of the buffer layer was also studied. Table 1 summarizes the values of short-circuit current density $\left(J_{s c}\right)$, open-circuit voltage $\left(V_{o c}\right)$, fill factor $(\mathrm{FF})$, and power conversion efficiency $(\eta)$ of inverted $\mathrm{TiO}_{2} / \mathrm{P} 3 \mathrm{HT}$ : PCBM/PEDOT/Ag and $\mathrm{Nb}_{2} \mathrm{O}_{5} / \mathrm{P} 3 \mathrm{HT}: \mathrm{PCBM} / \mathrm{PEDOT} /$ Ag solar cell. For $\mathrm{TiO}_{2}$ and $\mathrm{Nb}_{2} \mathrm{O}_{5}$ with one-cycle spin- coating, the devices present similar efficiencies around $2.7 \%-2.8 \%$. However, as increasing the spin-coating cycle, which leads to an increase in the film thickness, the

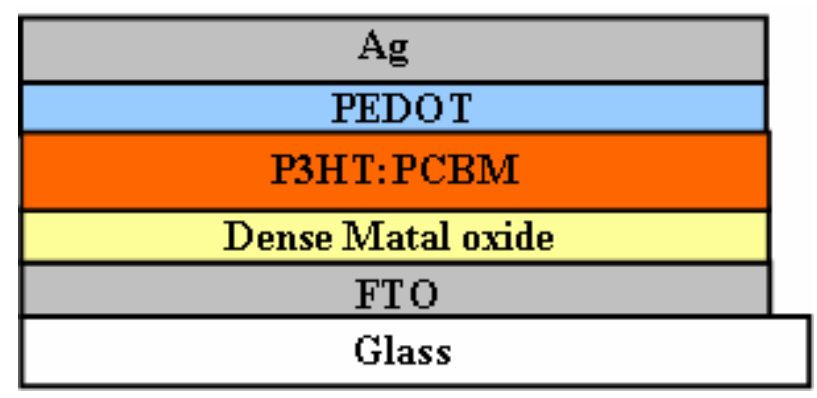

Figure 1. Schematic configuration of inverted structure polymer solar cell.

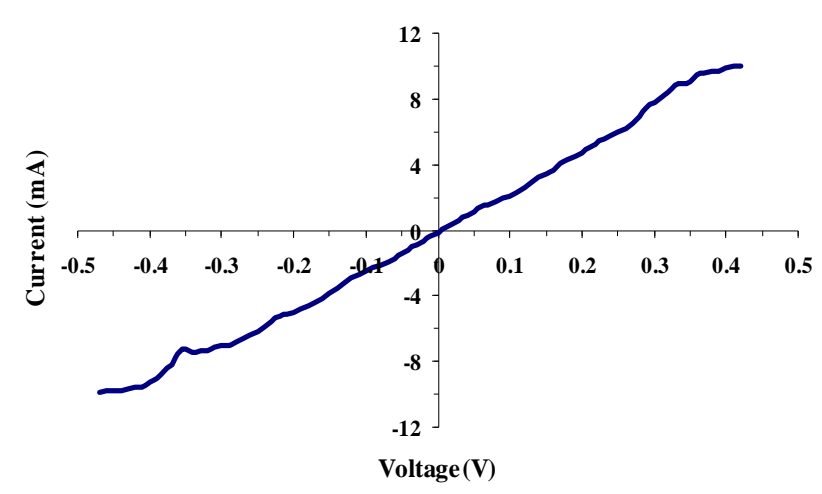

Figure 2. I-V curve for FTO/P3HT:PCBM/PEDOT/Ag. 




Figure 3. $J-V$ curves of the hybrid solar cells based on $\mathrm{TiO}_{2}$ and $\mathrm{Nb}_{2} \mathrm{O}_{5}$ thin film.

power conversion efficiency decreased from $2.8 \%$ to $2.3 \%$ in the case of $\mathrm{TiO}_{2}$ and decreased from $2.7 \%$ to even zero in the case of $\mathrm{Nb}_{2} \mathrm{O}_{5}$. Meanwhile, the shortcircuit current density and fill factor can be also seen a significant decrease.

Figure 4 shows schematic picture of the energetic levels of $\mathrm{Nb}_{2} \mathrm{O}_{5}, \mathrm{TiO}_{2}, \mathrm{PCBM}$ and P3HT. The conduction band (CB) of $\mathrm{TiO}_{2}$ is lower than the lowest occupied molecular orbital (LOMO) energy level of P3HT and PCBM which allows electrons to transport from LOMO energy level of PCBM into the $\mathrm{CB}$ of $\mathrm{TiO}_{2}$. Note that the conduction band of $\mathrm{Nb}_{2} \mathrm{O}_{5}$ is higher than the LUMO of PCBM. That means the electron transport from the LOMO energy level of PCBM into the $\mathrm{CB}$ of $\mathrm{Nb}_{2} \mathrm{O}_{5}$ is not possible. However, in our study as the results shown in Table 1, a power conversion of $2.7 \%$ was indeed achieved while $\mathrm{Nb}_{2} \mathrm{O}_{5}$ serves as the buffer layer. More importantly, the achieved efficiency $2.7 \%$ is approximately equal to that $(2.8 \%)$ obtained for $\mathrm{TiO}_{2}$ (Table 1). Such a scenario strongly suggests that the electrons seem to transfer from the PCBM to collecting electrode through a tunneling process, as shown in Figure 5. Along with an increase in the thickness of $\mathrm{Nb}_{2} \mathrm{O}_{5}$, it presents decreased short-circuit current density, open-circuit voltage, fill factor and power conversion efficiency. The efficiency even drops to zero in the case of thicker $\mathrm{Nb}_{2} \mathrm{O}_{5}$ film.

The above experimental observation that shows poor performance based on thick film indicates that excessively increased thickness of the dense metal oxide film beyond tunneling distance plays a negative role in the photovoltaic process. In other words, the transport of electrons unlikely occurs in a diffusion way in view of the receival of efficiency in the case of $\mathrm{Nb}_{2} \mathrm{O}_{5}$ and a quick decrease in the efficiency as slightly increased thickness of the buffer layer. Considering the fact that no photovoltaic response can be obtained in the absence of oxide buffer layer, the role of the oxide layer is believed to promote

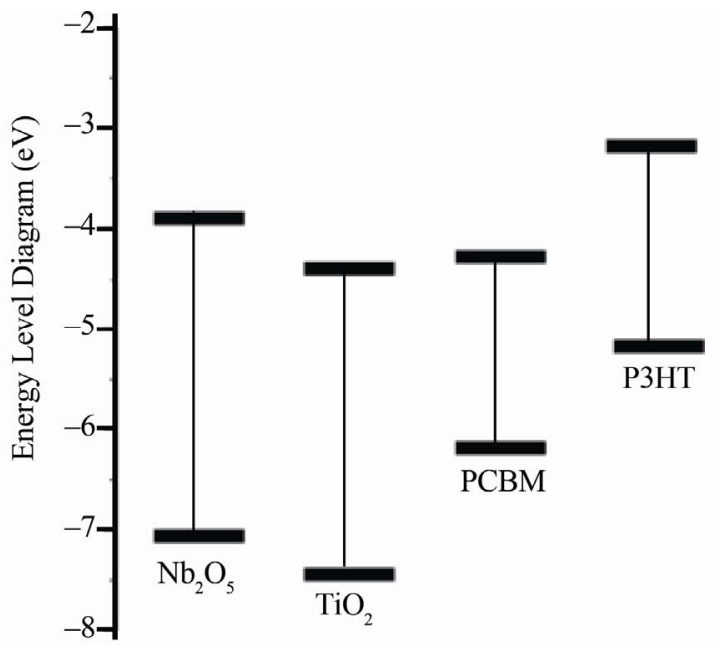

Figure 4. Schematic drawing of the energetic levels of $\mathrm{Nb}_{2} \mathrm{O}_{5}$, $\mathrm{TiO}_{2}, \mathrm{PCBM}$ and P3HT.

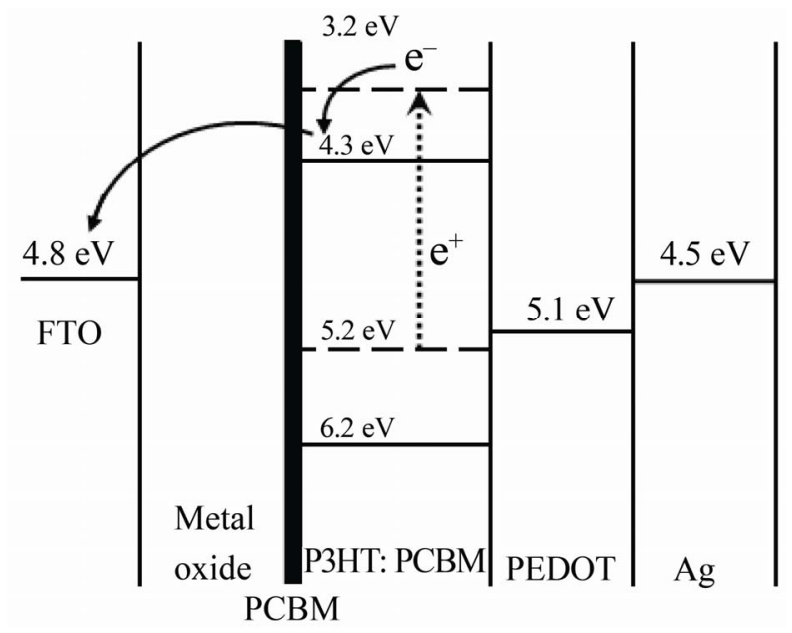

Figure 5. Energy diagram and charge transfer process of the as-discussed photovoltaic device with FTO/dense metal oxide/P3HT:PCBM/PEDOT/Ag structure.

Table 1. Summary of the performance of inverted structure polymer solar cells with buffer layer of $\mathrm{TiO}_{2}$ and $\mathrm{Nb}_{2} \mathrm{O}_{5}$.

\begin{tabular}{|c|c|c|c|c|c|}
\hline \multirow{2}{*}{$\begin{array}{l}\text { Metal } \\
\text { Oxide }\end{array}$} & \multirow{2}{*}{$\begin{array}{c}\text { Time } \\
\text { of } \\
\text { Cycle }\end{array}$} & $V_{o c}$ & $J_{s c}$ & \multirow[b]{2}{*}{$\mathrm{FF}(\%)$} & \multirow[b]{2}{*}{$\eta(\%)$} \\
\hline & & $(V)$ & $\left(\mathrm{mA} \cdot \mathrm{cm}^{-2}\right)$ & & \\
\hline \multirow{2}{*}{$\mathrm{TiO}_{2}$} & 1 & 0.574 & 8.95 & 53.9 & 2.8 \\
\hline & 2 & 0.602 & 8.87 & 43.1 & 2.3 \\
\hline \multirow{2}{*}{$\mathrm{Nb}_{2} \mathrm{O}_{5}$} & 1 & 0.602 & 7.94 & 55.8 & 2.7 \\
\hline & 2 & 0.32 & 1.08 & 24.7 & 0 \\
\hline
\end{tabular}

the formation of continuous uniform PCBM film so as to prevent the P3HT from touching with the FTO substrates and as such avoid the holes in P3HT from being recombined with the electrons in the collecting electrode. Therefore, charge separation in our hybrid solar cell occurs at the interface between P3HT and PCBM. 


\section{Conclusions}

Our study demonstrates that a thin oxide film coating on FTO glass substrate is necessary in inverted structure polymer solar cells to protect P3HT from touching the FTO substrates and promote the formation of continuous uniform PCBM film to block holes from being recombined. The electrons transport from the PCBM to the collecting electrode on FTO glass substrate through a tunneling process. A thick buffer layer would not allow the occurrence of electron tunneling and therefore leads to low efficiency or even no photovoltaic response in the inverted structure solar cells.

\section{Acknowledgements}

This work is funded by the US Department of Energy, Office of Basic Energy Sciences, Division of Materials Sciences, under Award No. DE-FG02-07ER46467 (Q.F.Z.). This work is also supported in part by the National Science Foundation (DMR 1035196), the Air Force Office of Scientific Research (AFOSR-MURI, FA9550-06-10326), the University of Washington TGIF grant, the Royalty Research Fund (RRF) from the Office of Research at University of Washington, the Washington Research Foundation, and the Intel Corporation, Office of the Higher Education Commission, Ministry of Education, Thailand. Orawan Wiranwetchayan was supported by CHE Ph.D. Scholarship, and partially supported by the Graduate School, Physics and Material Department, Faculty of Science, Chiang Mai University.

\section{REFERENCES}

[1] J.-C. Wang, W.-T. Weng, M.-Y. Tsai, M.-K. Lee, S.-F. Horng, T.-P. Perng, C.-C. Kei, C.-C. Yuc and H.-F. Mengd, "Highly Efficient Flexible Inverted Organic Solar Cells Using Atomic Layer Deposited $\mathrm{ZnO}$ as Electron Selective Layer," Journal of Materials Chemistry, Vol. 20, No. 29, 2010, pp. 862-866. doi:10.1039/b921396a

[2] S. K. Hau, H.-L. Yip, H. Ma and A. K.-Y. Jen, "High Performance Ambient Processed Inverted Polymer Solar Cells through Interfacial Modification with a Fullerene Self-Assembled Monolayer," Applied Physics Letters, Vol. 93, No. 23, 2008, pp. 233-304. doi:10.1063/1.3028094

[3] F. Zhang, X. Xu, W. Tang, J. Zhang, Z. Zhuo, J. Wang, J. Wanga, Z. Xu and Y. Wanga, "Recent Development of the Inverted Configuration Organic Solar Cells," Solar Energy Materials and Solar Cells, Vol. 95, No. 7, 2011, pp. 2758-2761. doi:10.1016/j.solmat.2011.02.002

[4] J.-S. Huang, C.-Y. Chou, M.-Y. Liu, K.-H. Tsai, W.-H. Lin and C.-F. Lin, "Solution-Processed Vanadium Oxide as an Anode Interlayer for Inverted Polymer Solar Cells Hybridized with ZnO Nanorods," Organic Electronics, Vol. 10, No. 3, 2009, pp. 1060-1065. doi:10.1016/j.orgel.2009.05.017
[5] W.-H. Baek, I. Seo, T.-S. Yoon, H. H. Lee, C. M. Yun and Y.-S. Kim, "Hybrid Inverted Bulk Heterojuntion Solar Cells with Nanoimprinted $\mathrm{TiO}_{2}$ Nanopores," Solar Energy Materials and Solar Cells, Vol. 93, No. 9, 2009, pp. 1587-1591. doi:10.1016/j.solmat.2009.04.014

[6] Y. Liang, Z. Xu, J. Xia, S.-T. Tsai, Y. Wu, G. Li, C. Ray and L. Yu, "For the Bright Future-Bulk Heterojunction Polymer Solar Cells Eith Power Conversion Efficiency of 7.4\%," Advanced Material, Vol. 22, No. 20, 2010, pp. 1-4. doi:10.1002/adma.200903528

[7] A. K. K. Kyaw, X. W. Sun, C. Y. Jiang, G. Q. Lo, D. W. Zhao and D. L. Kwong, "An Inverted Organic Solar Cell Employing a Sol-Gel Derived $\mathrm{ZnO}$ Electron Selective Layer and Thermal Evaporated $\mathrm{MoO}_{3}$ Hole Selective Layer," Applied Physics Letters, Vol. 93, No. 22, 2008, Article ID: 221107 . doi:10.1063/1.3039076

[8] M. Jørgensen, K. Norrman and F. C. Krebs, "Stability/ Degradation of Polymer Solar Cells," Solar Energy Materials and Solar Cells, Vol. 92, No. 7, 2008, pp. 686-714. doi:10.1016/j.solmat.2008.01.005

[9] K. Kawano, R. Pacios, D. Poplavskyy, J. Nelson, D. D. C. Bradley and J. R. Durrant, "Degrasation of Organic Solar Cells Due to Air Exposure," Solar Energy Materials and Solar Cells, Vol. 90, No. 20, 2006, pp. 3520-3530. doi:10.1016/j.solmat.2006.06.041

[10] F. C. Krebs, J. E. Carle, N. Cruys-Bagger, M. Andersen, M. R. Lilliedal, M. A. Hammond and S. Hvidt, "Lifetimes of Organic Photovoltaics: Photochemistry, Atmosphere Effects and Barrier Layers in ITO-MEHPPV," Solar Energy Materials and Solar Cells, Vol. 86, No. 4, 2005, pp. 499-516. doi:10.1016/j.solmat.2004.09.002

[11] J. Boucle, P. Ravirajanac and J. Nelson, "Hybrid Polymermetal Oxide Thin Films for Photovoltaic Applications," Journal of Materials Chemistry, Vol. 17, No. 30, 2007, pp. 3141-3153. doi:10.1039/b706547g

[12] S. Yodyingyong, X. Zhou, Q. Zhang, D. Triampo, B. Limketkai and G. Z. Cao, "Enhanced Photovoltaic Performance of Nanostructured Hybrid Solar Cell Using Highly Oriented $\mathrm{TiO}_{2}$ Nanorods," Journal of Physics Chemistry, Vol. 114, 2010, pp. 21851-21855.

[13] R. Zhu, C. Y. Jiang, B. Liu and S. Ramakrishna, "Hyghly Efficient Nanoporous $\mathrm{TiO}_{2}$-Polythiophene Hybrid Solar Cells Based on Interfacial Modification Using a MetalFree Organic Dye," Advanced Materials, Vol. 21, No. 9, 2009, pp. 994-1000. doi:10.1002/adma.200802388

[14] J.-S. Huang, C.-Y. Chou and W.-H. Lin, "Enhancing Performance of Organic-Inorganic Hybrid Solar Cells Using a Fullerene Interlayer from All-Solution Processing," Solar Energy Materials and Solar Cells, Vol. 94, No. 10, 2010, pp. 182-186. doi:10.1016/j.solmat.2009.08.019

[15] M. N. Shan, S. S. Wang, Z. Q. Bian, J. P. Liu and Y. L. Zhao, "Hybrid Inverted Organic Photovoltaic Cells Based on Nanoporous $\mathrm{TiO}_{2}$ Films and Organic Small Molecules," Solar Energy Materials and Solar Cells, Vol. 93, No. 9, 2009, pp. 1613-1617. doi:10.1016/j.solmat.2009.04.017

[16] T. Yang, W. Cai, D. Qin, E. Wang, L. Lan, X. Gong, J. 
Peng and Y. Cao, "Solution-Processed Zinc Oxide Thin Film as a Buffer Layer for Polymer Solar Cells with an
Inverted Device Structure," Journal of Physics Chemistry, Vol. C114, 2010, pp. 6849-6853. 